\title{
Environmental changes of Nepal Himalaya in terms of GLOF phenomena
}

\author{
Hiroji Fushimi \\ Kathmandu University, Nepal \\ (E-mail: fushimih@hotmail.co.jp)
}

\begin{abstract}
As in the othe parts of Nepal, the environment of the Greater Himalaya is also rpidly changing with huge impacts on glacier, glacial lakes and GLOF occurrences. This paper briefly describes the environmental changes and GLOF characteristics in Nepal Himalaya.
\end{abstract}

Paper Received: 09 May 2015

Paper Accepted: 21 February 2016

\section{INTRODUCTION}

The author is observing the environmental changes in Nepal since 1965, when the Kathmandu valley breathed fresh crisp air and towering Himalayas could be clearly sighted from the valley as well as various species of fishes were found in the clear Bagmati River. However, now-a-days, the mountains and hills are hidden by thick smog and choking dust and the Bagmati River is full of waste, stench and filth. In 1960's and 1970's, there were many cows and dogs in streets clearing up the waste and raw vegetables where there were almost no plastic products and there was fortunately a sustainable circulation in the Kathmandu life environment that is now completely destroyed.

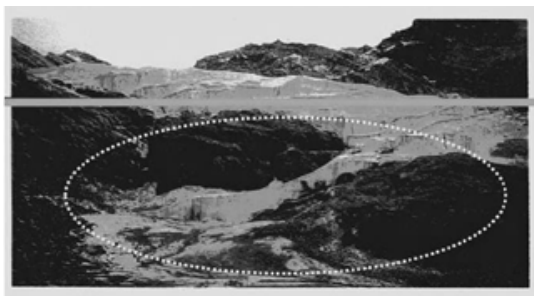

Kongma-tikpe Glacier, Khumbu, East Nepal

ELA in 1976

The lower part of the Kongma-tikpe Glacier in 1976 was almost melted away in 1995 shown below by the yellow dotted line.

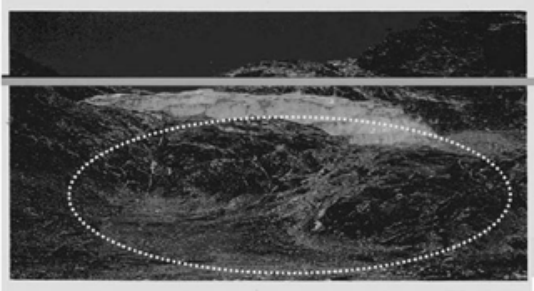

ELA in 1995

The upper part of the glacier locates below the ELA in 1995 while it was in the middle part of the glacier in 1976 shown above.

Fig. 1: Changes of perennial snow path in the Kongma Glacier, Khumbu region, east Nepal.

The Gyajo Glacier is an important water resource for Namche Bazar and the near-by villages in the Khumbu region and that is why they are working hard to construct a water pipe from the Gyajo Glacier (Fig. 3), but the local people may lose their water resource in near future. Such a case happened 5
Similar kind of the great change is observed in the Himalayan glacial phenomena. Fig. 1 shows the Kongma Glacier located near the Khumbu Glacier of Mt. Everest, the ELA (Equilibrium Line Altitude) located in the middle of the glacier indicating a heathy glacier in 1970's, but now it is higher than the glacier altitude meaning all parts of the glacier are in an ablation area. That is why the glacier melts very fast. The Gyajo Glacier (Fig. 2) near Namche Bazar was also a healthy glacier in 1970, but it is retreated very rapidly and lost a parennial snow pacth in 2009. These glaciers located below $7000 \mathrm{~m}$ might be desapeared in the middle of this century.
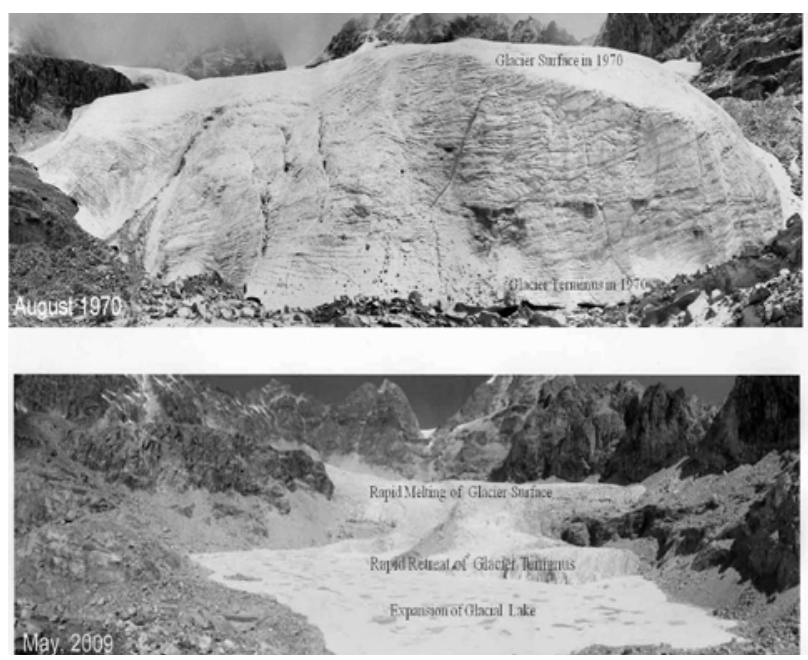

Fig. 2: Changes into a perennial snow patch in 40 years at Gyajo Glacier, Khumbu region, east Nepal.

years ago in Mustang, where people had to leave their villages as an environmental refugee due to the deficiency of water resource caused by the disappearance of glaciers (Myrepublica, 2010). This paper is mainly based on the fieldworks since 1970 in the Nepal Himalaya, and not from desk work. 


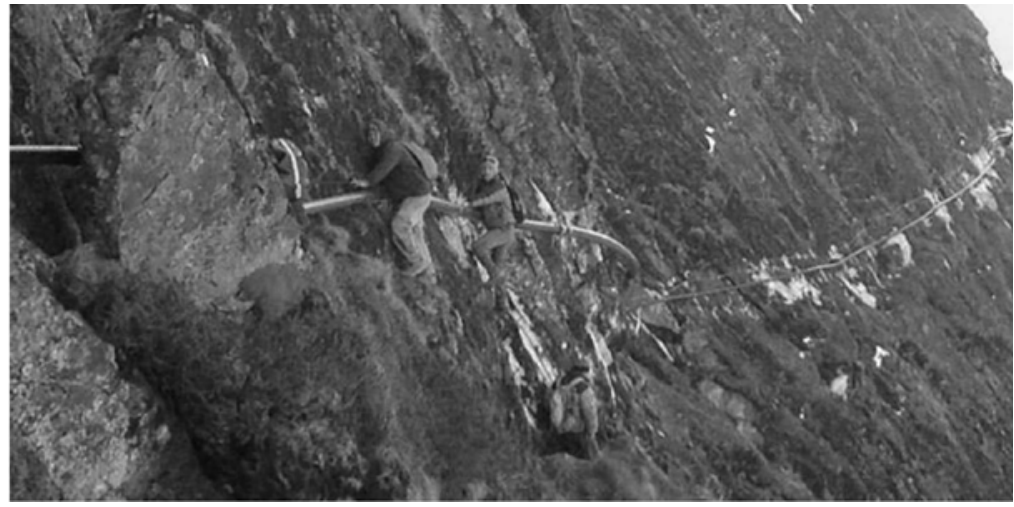

Fig. 3: Construction of the water pipe from Gyajo Khola, Namche Bazar area.

\section{GLOF CHARACTERISTICS OF NEPAL HIMALAYA}

Since 1970, many glaciers in Nepal Himalaya are receding and at the same time, glacial lakes are expanding in the Khumbu region of east Nepal. The Mingbo Glacial Lake Outburst Flood (GLOF) occurred in 1977. After that, the Lagmoche GLOF in 1985 and the Saboi GLOF in 1998 occurred in the Khumbu region (Fig. 4). These reported GLOFs occurred due to outburst of smaller glacial lakes with less than $1 \mathrm{~km}^{2}$, but there is no record of lake outbursts of larger glacial lakes such as Imja and Tso Rolpa. The valleys eroded by GLOF are clearly seen even in the satellite image shown by the white line due to the eroded valley topography (Fig. 4).

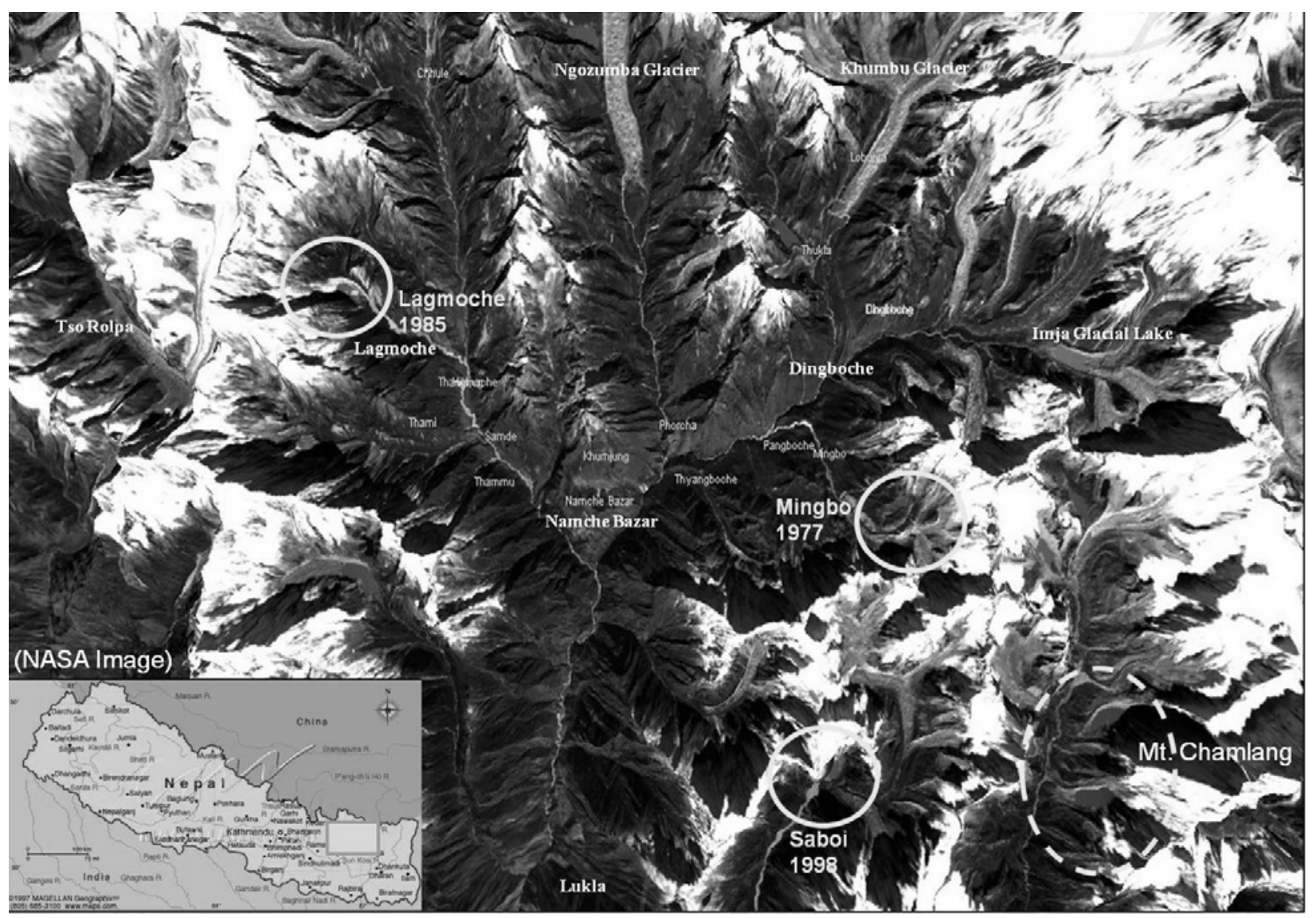

Fig. 4: GLOF map of the Khunbu region, east Nepal. Circle shows the GLOF from small lakes, dashed lines are the lakes (the smaller being at high GLOF risk in future). 


\section{Mingbo (Nare) GLOF}

The Mingbo (Nare) glacial lake was located in the south of Mt. Ama Dablam, Khumbu region. On 3 September, 1977, the lake caused the GLOF (Fig. 5) when we were doing glaciological surveys in the region. So, we went up along the eroded Minbo valley caused by the GLOF (Left photo) and observed the vacant lake $300 \mathrm{~m}$ long, $200 \mathrm{~m}$ wide and $30 \mathrm{~m}$ deep with the terminal moraine destroyed (Upper right). There was an ice-cored moraine (Left photo).
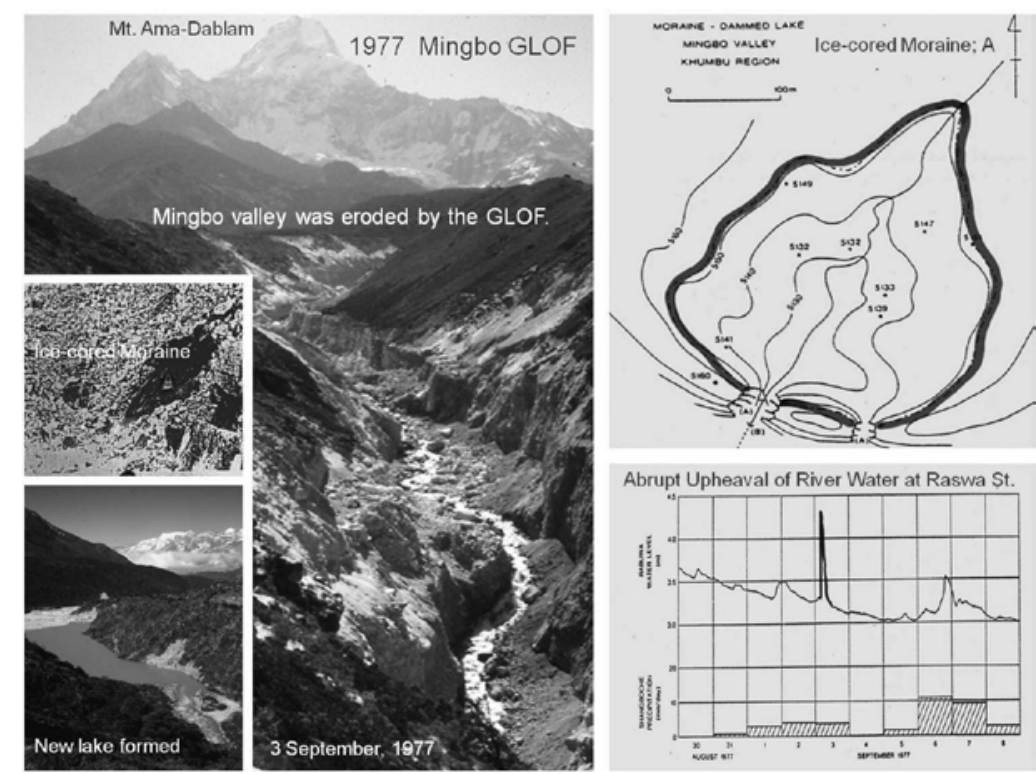

Fig. 5: 1977 Mingbo GLOF In the left phot, Mingbo valley eroded, Ice coreed moraine and newly formed lake are shown, and the vacant lake and Dudh Kosi hydrograph in the right figure.

Due to the large amount of debris caused by the GLOF, a new lake was formed in the Imja Khola near Pangboche (Lower left photo), while the river level of Dudh Koshi was raised abruptly about $1 \mathrm{~m}$ at Raswa Hydrological Station (Lower right). So, the GLOF has destructed roads, bridges and houses near the river bed along the Dudh Koshi.

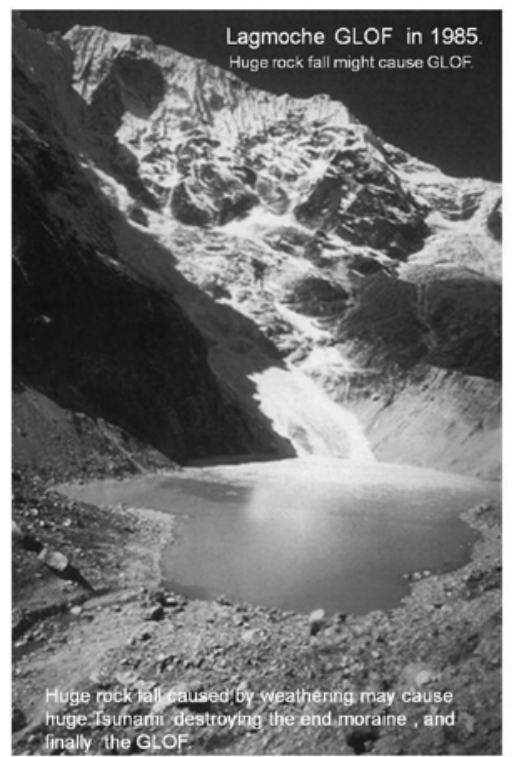

\section{Langmoche GLOF}

The Langmoche (Digtso) glacial lake near Thame in the western part of the Khumbu region has the steep cliff causing avalanches and rocks directly falling into the lake and huge waves (Tsunami) possibly destroyed the end moraine (Upper right photo) and villages along the river (Lower right photo) by the 1985 GLOF (Fig. 6).

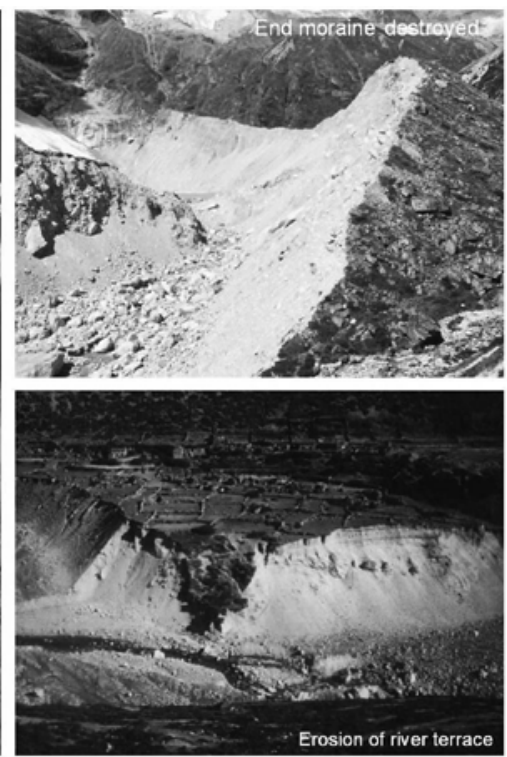

Fig. 6: Langmoche (Digtso) glacial lake near Thame in the western part of the Khumbu region. End-moraine was destroyed at the 1985 GLOF and the GLOF disaster was reported along the Dudh Koshi. 


\section{Sabai GLOF}

Fig. 7 is the picture of the Sabai glacial lake as well as its glacier taken from a plane and in field survey of 1976. The Sabai glacial lake in the south-eastern part of the Khumbu region lies on Hinku Khola and has also the steep cliff in the upper part of the lake (Fig. 7). The end moraineof the lake was probably desroyed by a kind of Tsunami due to the avalanche or rock fall from the steep cliff at the time of the 1998 GLOF.

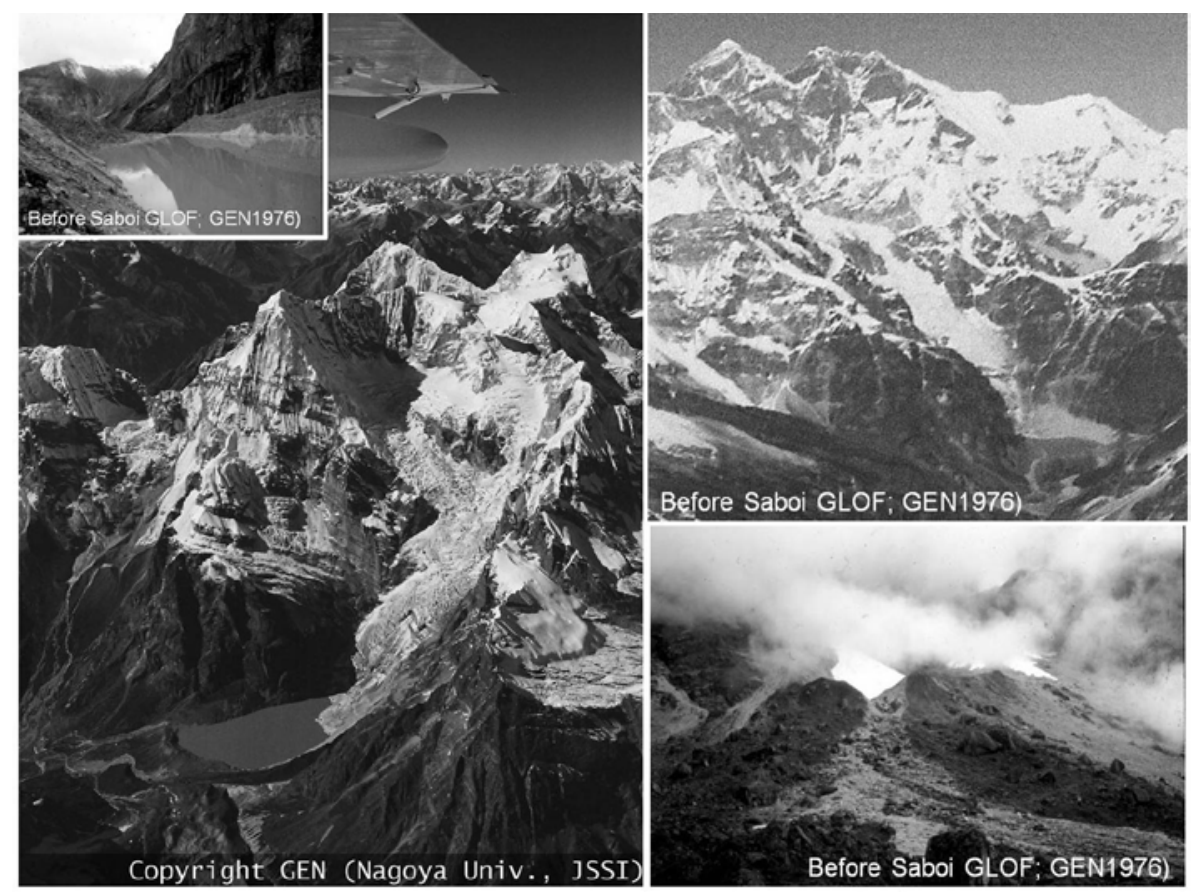

Fig. 7: Sabai glacial lake is in the south-eastern part of the Khumbu region and has a steep clif in the upper part of the lake.

\section{Gabche GLOF}

The Gabtse glacial lake is located at the south side of Mt. Annapurna II in the central Nepal Himalaya. The field observation in May, 2012 revealed that it is the lowest glacial lake with altitude of $2,500 \mathrm{~m}$ asl in Nepal Himalaya and there is a quite large cliff, the altitude difference of which is about 4,000 m, in the upper part of the glacial lake. Frequent avalanches and rock falls from Mt. Annapurna II and Lamjung Himal create a Tsunami to cause GLOF when they fall directly into the lake. The GLOF disaster occurred along the Madi Khola in 2003, 2005 and 2009 according to the local residents.

\section{Thulagi glacial lake as a large glacial lake}

The Thulagi glacial lake is one of the large glacial lakes and is located at the upper part of Dana Khola, the Marshangdi's tributary river in the west of Mt. Manaslu and Mt. Peak 29. Ther is no eroded valley topography caused by GLOF along Dana Khola below the river mouth of the Thulagi glacial lake.

\section{Glacial changes}

The changes of the Thulagi glacial lake and its glacier terminus were determined by air photos and field surveys. The lake size is $3 \mathrm{~km}$ long, $0.5 \mathrm{~km}$ wide and expanded at yearly rates of $31 \mathrm{~m}$ from 1975-1992, $47 \mathrm{~m}$ from 1992-2005, $68 \mathrm{~m}$ from 2005-2008, $60 \mathrm{~m}$ from 2008-2009 and no significant change from 2009-2014 (Fig. 8). The recent changing rate had been accelerating with active calving from 1975 to 2009, but it seems to be settled down and show no remarkable calving phenomena since 2009. The terminus of the Thulagi glacier was thought to have stranded on the lake bed.

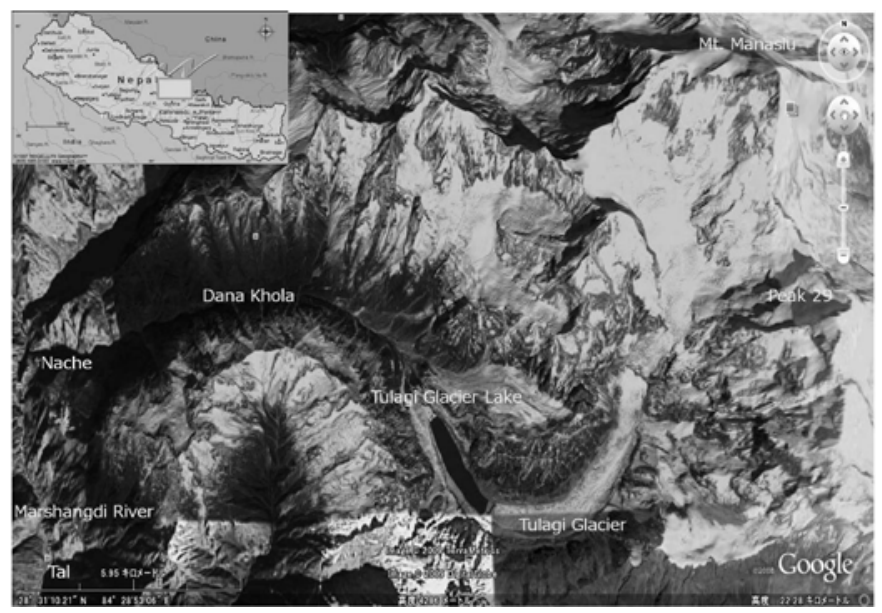

Fig. 8: The changes of the Thulagi glacial lake and its glacier terminus.

The Thulagi glacial lake has the huge debris covered glacier in the upper part receiving avalanches and rockfalls 
from Mt. Manaslu and Mt. Peak 29, which is completely different from the small glacial lakes having the avalanches and rock falls dropping directly into the lake.

\section{Recent changes of the lake level}

As Department of Hydrology and Meteorology (DHM) made a glaciological survey in 1996, the topographic characteristics were compared with the photographs of 1996 and 2009 in the lower part of the lake, and the lowering of the lake level is clearly shown by the yellow arrows and a clean pond is newly formed due to the sedimentation of glacial clay at $\mathrm{P}$ point (Fig. 9).

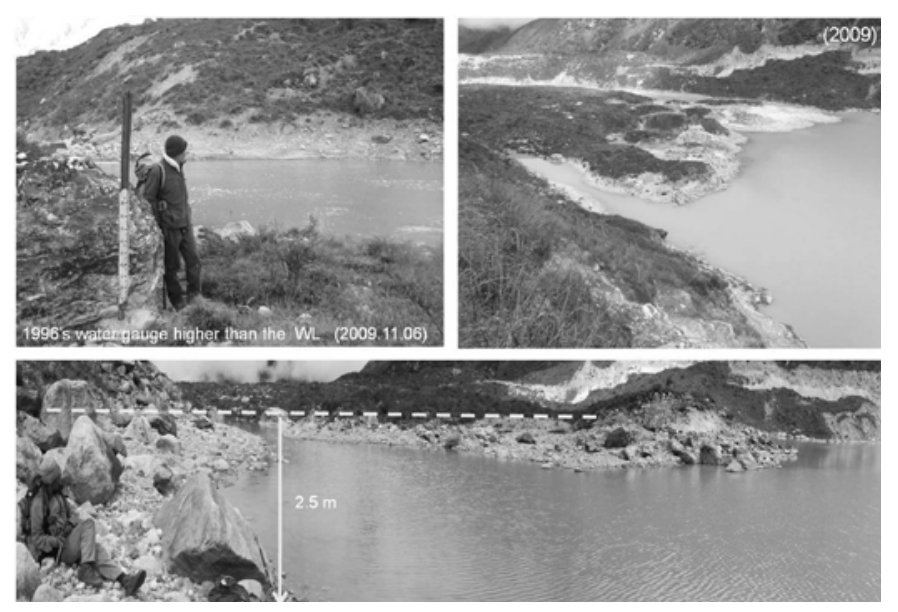

Fig. 9: The white arrows show the lowering of Thulagi lake level form 1996 to 2009.

The shore line without vegetation is $2.5 \mathrm{~m}$ above the present lake level and the 1996 water gauge has been left higher than the present lake level The lake level lowered $2.5 \mathrm{~m}$ from 1996 to 2009.

\section{Glacial history of the neoglaciation}

The plant remnants were sampled from the moraine basement of the Thuklha stage in the Khumbu region. Since the ${ }^{14} \mathrm{C}$ age of the sample is $410 \pm 110 \mathrm{yr}$ B.P., the age of the Thuklha stage is the $16^{\text {th }}$ century, beween $15^{\text {th }}$ and $17^{\text {th }}$ century in the neoglaciation (Fushimi 1981).

Fushimi (1981) reported that the Thulagi glacial lake was formed after the glacial advance in $16^{\text {th }}$ century in the neoglaciation and there is no evidence of the GLOF occurrence indicated by a newly formed river terrace with an eroded valley topography along Dana Khola. At the end-moraine of Thulagi glacial lake between the lower part of the lake and the most upper part of Dana Khola, the river mouth (outlet) is eroded about $30 \mathrm{~m}$ from the top of the end moraine formed in $16^{\text {th }}$ century. So, the water level of Thulagi glacial lake has been lowered at the average annual rate of $5 \mathrm{~cm}$ due to the outlet erosion at the end moraine since the glacial advance of $16^{\text {th }}$ century that indicates to decrease the GLOF risk.

\section{Moraine structure}

The end moraine structure of the Thulagi glacial lakes is wide and strong enough to prevent the occurrence of the GLOF. The lake level of the Thulagi glacial lake has been continuously lowered by the outlet erosion at the end moraine to decrease the GLOF risk and it is occurred without having a man-made canal. The Thulagi glacial lake is thought to have a kind of an autonomous property to prevent the GLOF.

\section{Imja glacial lake}

Fig. 10 shows the Imja glacial lake taken in 1975 by plane, and in 2002 (upper left photo in Fig. 10) and 2013 (lower left photo in Fig. 10) taken during the field study. The size of Imja glacial lake expanded from 1975 to 2002, but reduced in 2013. The end moraine structure of Imja glacial lake is also wide and strong enough to prevent the occurrence of the GLOF. ICIMOD (2011) reported that Imja glacial lake has less likelihood of out burst than Thulagi lake.

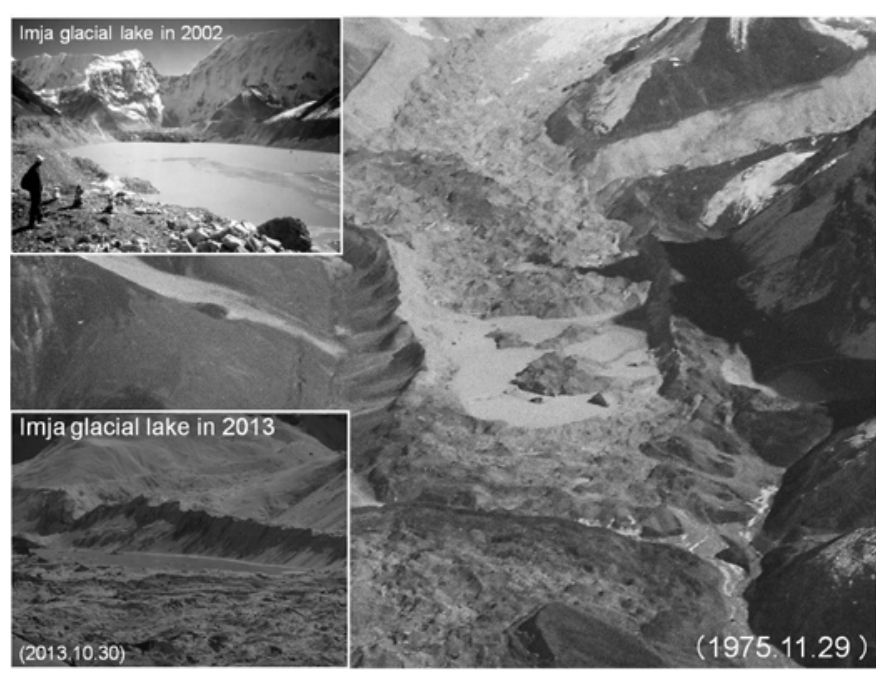

Fig. 10: Changes of the Imja glacial lake from 1975 to 2013.

\section{CONCLUSIONS}

All the reported GLOFs within Nepal Himalaya are outburst of smaller glacial lakes. Larger glacial lakes such as Thulagi, Imja and Tso Rolpa exhibited no GLOF phenomena before. Due to the erosion of the outlet at the end moraine of the larger glacial lake since the 16th century glacial advance, the lake level has been always lowering and reducing the GLOF risk without having a man-made canal.

The Imja glacial lake is considered to have less likelihood of out burst than the Thulagi glacial lake. However, Thulagi glacial lake itself safe agaiust GLOF due to an erosion at the end moraine. Thus, both the large glacial lakes such as Thulagi and Imja are safe against GLOF. Thus, we must be very careful about the small glacial lakes. Therefore, such small glaciers must be subjected to mitigation works against GLOF. 


\section{REFERENCES}

Fushimi, H., 1981, Glacial history in the Khumbu Region, Nepal Himalayas in relation to upheavals of the Great Himalayas. (In: Geological and Ecological Studies of Qinghai-Xizang Plateau, Symposium on Qinghai-Xizang (Tibet) Plateau, Beijing, China, 25 May-2 June 1980. Proceedings, v. 2. Bejing, Science Press, New York, Gordon and Breac, pp. 1641-1648.
Ghimire, M. K., Dwivedi, S., and K. C., S. 2005, Glacial study in Madi watershed with special reference to GLOF of 2003. Jour. Nepal Geol. Soc., v. 32 (Sp. Issue), pp. 48-48.

ICIMOD, 2011, Glacial lakes and glacial lake outburst floods in Nepal. ICIMOD, Kathmandu, 96 p.

Myrepublica, 2010, Nepal's first climate refugee village in Mustang, 2010-06-01, http://archives.myrepublica.com/ portal/?action=news_details\&news_id=19341 